Article

\title{
Physiological Factors and their Relationship with the Productivity of Processing Tomato under Different Water Supplies
}

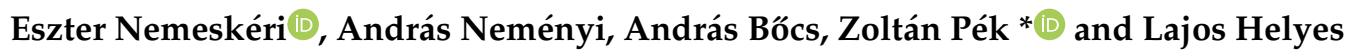 \\ Institute of Horticulture, Szent István University, Gödöllő, H-2100 Gödöllő, Hungary; \\ Nemeskeri.Eszter@mkk.szie.hu (E.N.); Nemenyi.Andras@mkk.szie.hu (A.N.); dr.andras.bocs@gmail.com (A.B.); \\ Helyes.Lajos@mkk.szie.hu (L.H.) \\ * Correspondence: Pek.Zoltan@mkk.szie.hu; Tel.: +36-28-522071
}

Received: 4 March 2019; Accepted: 15 March 2019; Published: 21 March 2019

check for updates

\begin{abstract}
Measurement of physiological traits can be used to monitor plant water status, for irrigation scheduling or to predict the expected yield in open-field production of vegetables. This study evaluates the changes in stomatal conductance, chlorophyll fluorescence $(\mathrm{Fv} / \mathrm{Fm})$, relative chlorophyll content (SPAD), and canopy temperature at different stages of development of processing tomato to show their relationships with the yield and quality under well-irrigated, deficit irrigated, and non-irrigated conditions. Under non-irrigated conditions, during flowering with fruit setting and early fruit development the highest canopy temperature, lowest stomatal conductance, and Fv/Fm were measured, while the SPAD value was the highest. Under this condition, the correlation between the SPAD value, fruit weight, and marketing yield was positive, but it was negative with the total soluble solid ( ${ }^{\circ}$ Brix). During flowering with fruit setting, under deficit irrigation conditions a close significant positive correlation was found between the SPAD value and the fruit weight, marketing yield, and vitamin $C$ content of fruits. During this period, under regularly irrigated conditions, the SPAD, Fv/Fm, and canopy temperature related to stomatal conductance. Stomatal conductance had significant influence on yield and quality under non-irrigated and well-irrigated conditions while the SPAD value and canopy temperature had significant influence on under deficit irrigated conditions.
\end{abstract}

Keywords: tomato; deficit irrigation; chlorophyll fluorescence; SPAD; stomatal conductance; yield quality

\section{Introduction}

Tomato (Lycopersicon esculentum Mill.) is one of the vegetables with the highest economic values in the world. Recently, there has been an increase in the consumption of various tomato products, therefore large amounts of good quality raw materials need to be grown for the processing industry to satisfy consumer demands. The morphological qualities of yield such as size, form, and colour of the fruits and the large dry matter content of the fruits are important for the processing industry. Nevertheless, many factors influence the accumulation of the dry matter content of fruits, which depends on the variety, the maturity of the tomato fruit, and environmental factors including heat, radiation, nutrients, and water supply conditions [1,2].

Tomato is considered to be a high water-demanding crop [3]. The period from fruit set to the end of fruit development is the most sensitive to water deficiency. During this time, the damage caused by a water deficit can be mitigated using irrigation technologies [1] but the time and dose of irrigation is important. Late and over-irrigation result in a decrease of the yield [4,5] and reduce the yield quality [6]. 
Irrigation scheduling requires a more scientific basis, including the knowledge of the plant response to water stress, in order to determine the timing of irrigation and the applied water amount $[7,8]$. Under drought, plants reduce water loss by stomatal closure which results not only in a reduction of transpiration but the inhibition of photosynthesis coupled with reducing $\mathrm{CO}_{2}$ uptake [9]. As a result of decreasing photosynthesis, the amount of available metabolites required for the development of plants decreases [10,11], therefore the height and yield of plants decrease [12]. The photosynthetic activity of the crops is one of the important factors influencing the yield that can be monitored by the measurement of physiological traits such as chlorophyll content of leaves, net photosynthetic rate, and stomatal conductance [13]. These characteristics can be used to evaluate the drought tolerance of the varieties and the timing of irrigation $[14,15]$. The change in canopy temperature indicates the necessity of the irrigation [16]. The measurement of stomatal conductance can be used to monitor the water status of plants [17] and predict the expected yield [18,19]. It has been established that irrigation results in an increase in the yield of tomato and a decrease in the total soluble solid of tomato fruits; however, the dry matter yield per hectare increases [20]. Nevertheless, slight water stress can maintain the yield and nutritional quality of tomato fruits at an optimum level [21,22], and improve water use efficiency [23].

Photosynthetic activity can be measured indirectly with the measurement of the efficiency of the photochemistry systems (PSI-PSII) as well as that of the photosynthetic pigments in the leaves. The excitation energy that is not used for photosynthesis is either emitted as fluorescence or is released as heat [24]. The maximum photochemical quantum yield of PSII (i.e., Fv/Fm) informs us of the state of undisturbed photosynthesis $[25,26]$. Under stress conditions, chlorophyll fluorescence ( Fv / Fm) changes depending on the genotype [27] therefore it was considered to be suitable for the characterization of drought tolerance [14,28-30]. Stress factors change leaf reflectance in the visible wavelengths and the metabolic disturbance also results in a change in the chlorophyll content of the leaves [31,32]. The portable chlorophyll meter provides a non-destructive method for the measurement of the light absorption of leaves and the calculated SPAD values are proportional to the amount of chlorophyll content of leaves. The measurement of SPAD can be used to evaluate the drought tolerance of genotypes and the productivity of some varieties grown under water deficiency $[18,33]$.

Although there have been a number of studies conducted on the effect of irrigation on the responses of tomato, the knowledge of the characteristics influencing photosynthesis and their relationships with the yield and quality of processing tomato are scarce under different water supplies. The objective of this study was to evaluate the change in some physiological traits at different stages of development of processing tomato under different water supply conditions. In addition, the objective was to analyze the relationship of these physiological traits with the expected marketing yield and quality.

\section{Materials and Methods}

\subsection{Experimental Design}

In the three years selected from a range of experiments between 2011 and 2016, the growth of Uno Rosso F1 processing tomato with middle period ripening was monitored under different water supply conditions in outdoor field experiments. The experiments were conducted at the Educational Farm of the Institute of Horticulture of Szent István University, Gödöllo, Hungary. The soil type was classified as Calcaric Arenosol, sandy loam in texture, consisted of $69 \%$ sand, $22 \%$ silt, and $9 \%$ clay, $1.57 \mathrm{~g} \mathrm{~cm}^{-3}$ bulk density, $19 \%$ field capacity, neutral in $\mathrm{pH}$, free from salinity $\left(0.16 \mathrm{dS} \mathrm{m}^{-1}\right)$, and low in organic carbon, $\mathrm{NO}_{3}{ }^{-}-\mathrm{N}_{\mathrm{KCl}}\left(5 \mathrm{~g} \mathrm{~kg}^{-1}\right), \mathrm{P}_{\mathrm{AL}}\left(6.6 \mathrm{~g} \mathrm{~kg}^{-1}\right), \mathrm{K}_{\mathrm{AL}}\left(29.1 \mathrm{~g} \mathrm{~kg}^{-1}\right)$. Regarding the water supply, the experimental data of dry years (2011 and 2015) and a mild wet year (2016) were analyzed. Four-week-old tomato seedlings were planted in the field on 29 April 2011. Tomato seedlings were planted in twin rows, with $0.4 \mathrm{~m}$ spacing inside the rows and $1.2 \mathrm{~m}$ between adjacent twin rows. The space between plants in a row was $0.3 \mathrm{~m}$, with a plant density of 4.2 plants $/ \mathrm{m}^{-2}$. In 2015 and 
2016, the tomato seedlings were planted on the 4th and 11th of May, respectively, at a plant density of 6.3 plants $/ \mathrm{m}^{-2}$ where the distance between the twin rows was the same as that in 2011 but the space between the plants differed $(0.2 \mathrm{~m})$.

The determination of water demand of plants was done using AquaCrop v5.0 software (Land and Water Division, Food and Agriculture Organization of the United Nations, Rome, Italy) [34]. Reference evapotranspiration (ET0) was calculated by the software according to the Food and Agriculture Organization (FAO) Penman-Monteith method corrected by the crop coefficient (Kc) [35]. The required meteorological parameters for the calculation were the following: daily minimum and maximum temperature, rain, wind, and mean relative humidity which was gathered from a meteorological station installed near the field. The following irrigation treatments were applied: WI-regular irrigation corresponding to the optimal water demands of plants (100\% of evapotranspiration), DI-deficit irrigation provided with half of the irrigated doses of WI treatment, and I0-non-irrigated plots were only under natural precipitation conditions (Table 1, Figure 1). Each treatment was carried out in a randomized block with four repetitions. A drip irrigation system was applied two times per week and it was ended 19 days before harvest. Five plants were selected for the measurements in each plot of all irrigated and non-irrigated treatments.

Table 1. Precipitation and irrigation water during the tomato cropping cycle from planting to harvest.

\begin{tabular}{ccccccc}
\hline Year & Precipitation $(\mathbf{m m})$ & \multicolumn{2}{c}{ Irrigation $(\mathbf{m m})$} & \multicolumn{3}{c}{ Total Water $\left.^{\mathbf{1}} \mathbf{( m m}\right)$} \\
\hline & & DI & WI & I0 & DI & WI \\
\hline 2011 & 162.4 & 161.0 & 324.5 & 162.4 & 323.4 & 486.9 \\
2015 & 175.6 & 140.6 & 262.5 & 175.6 & 316.2 & 438.1 \\
2016 & 315.1 & 112.6 & 211.5 & 315.1 & 427.7 & 526.6 \\
\hline \multicolumn{2}{r}{${ }^{1}$ I0 $=$ non-irrigat }
\end{tabular}

${ }^{1} \mathrm{I} 0=$ non-irrigated, $\mathrm{DI}=$ deficit irrigated, $\mathrm{WI}=$ regularly irrigated conditions.

\subsection{Measurements}

The Uno Rosso F1 tomato has been investigated under different water supply conditions from the years 2011 to 2016, but the effect of water supply on physiological traits and their relationship with the yield and quality could only be well evaluated in some years. In dry years $(2011,2015)$ the stomatal conductance and canopy temperature were measured. Stomatal conductance was measured by an AP4 (Delta T Devices Ltd., Cambridge, UK) type porometer on the leaf located below the upper flower cluster. The measurements were performed every day between 10:00 and 15:00 hours on three occasions: at the beginning of flowering (ST1), during flowering with fruit setting (ST2), and early fruit development (ST3) stages. The canopy temperature was ground-based measured by a Raytek MX4 (Raytek Corporation, Santa Cruz, CA, USA) handheld infrared remote thermometer, at the same time as described for measurements of stomatal conductance. It has a distance to spot ratio (D:S) of 60:1 \pm $0.75 \%$ accuracy, so spot diameter was $19 \mathrm{~mm}$ standing $1.15 \mathrm{~m}$ from the plant canopy, which allows targeting of a selected leaf area without disturbing ground or sky.

In a dry (2015) and a mild wet (2016) year, the chlorophyll content of leaves and chlorophyll fluorescence were measured. The measurement of the chlorophyll content of leaves was carried out by a SPAD 502 (Minolta, Warrington, UK) portable chlorophyll meter and it was given as a SPAD value. A PAM 2500 (Walz, Effeltrich, Germany) portable fluorometer was used to measure the chlorophyll fluorescence of leaves. The fluorometer measured the initial $\left(\mathrm{F}_{0}\right)$ and maximal $(\mathrm{Fm})$ fluorescence on dark-adapted samples, where four fully developed top leaves of selected plants from each replicate were affixed with leaf clips for a 35 min dark adaption before fluorescence measurement. The maximum photochemical quantum yield of photochemical system II (PSII) was calculated using the Fv/Fm ratio determined by the fast kinetics method in the PamWin 3.0 software (Walz, Effeltrich, Germany) [36], where the maximum quantum yield of PSII $(\mathrm{Fv} / \mathrm{Fm})$ expressed from the chlorophyll fluorescence 
was calculated on the basis of the equation: $\mathrm{Fv} / \mathrm{Fm}=\left(\mathrm{Fm}-\mathrm{F}_{0}\right) / \mathrm{Fm}$, where $\mathrm{F}_{0}=$ initial fluorescence, $\mathrm{Fm}=$ maximal fluorescence, and $\mathrm{Fv}=$ variable fluorescence $\left(\mathrm{Fm}-\mathrm{F}_{0}\right)$.

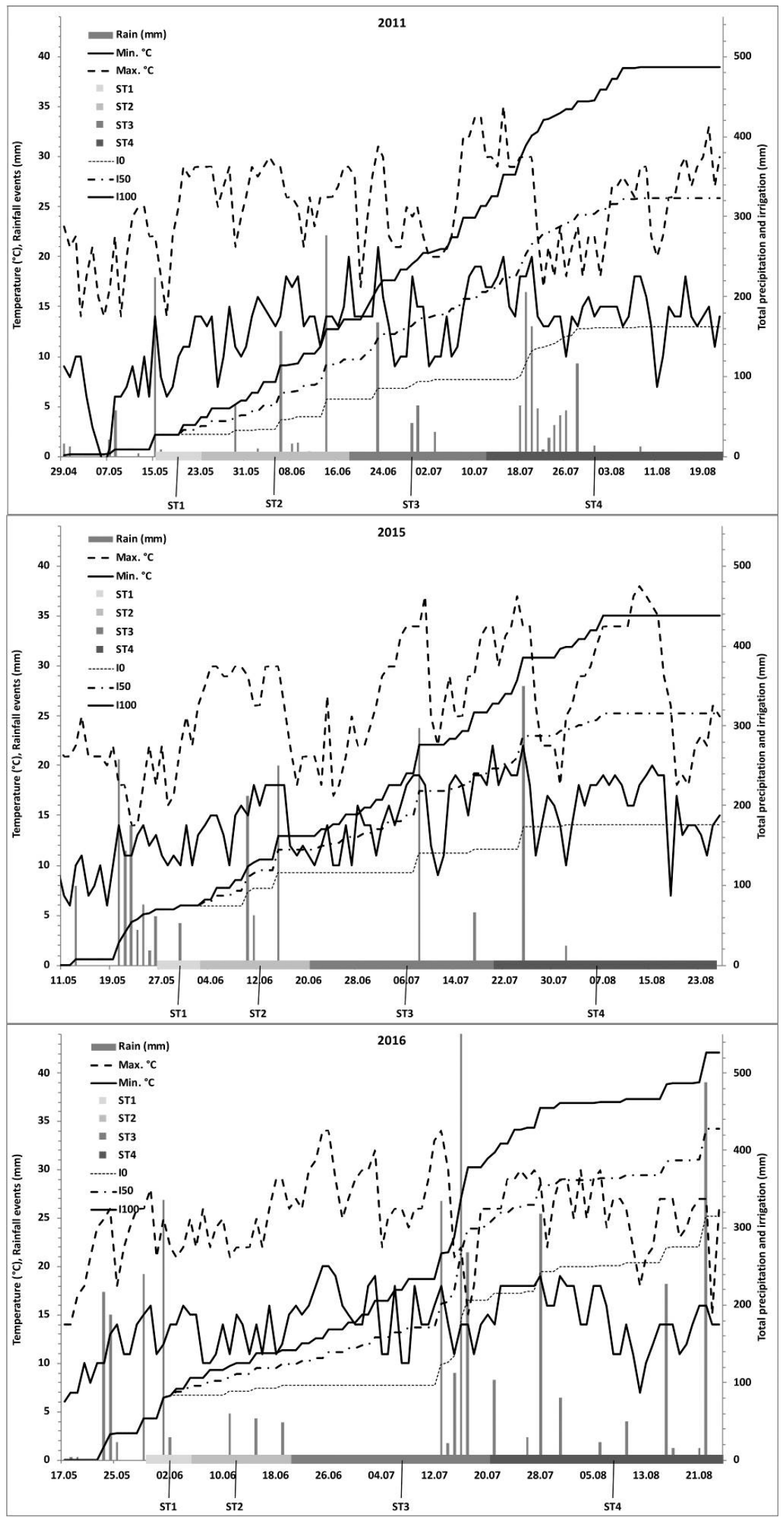

Figure 1. Meteorological and irrigation data during the growth stages of processing tomato. 
These measurements were carried out on the selected plants from ST1 to ST3 stage of development on the same days and time as that of stomatal conductance in all water supplies for 2015. In 2016 the days and time of the measurements of SPAD and Fv/Fm on the selected plant from ST1 to ST3 stages were the same as in 2015.

\subsection{Yield Analysis}

The selected plants were harvested between the 21th and 30th of August depending on the year. After harvest the yield was weighed and classified into three groups. The marketable group (1) was comprised of the healthy uniform sized and red colored tomato fruits. The healthy green immature fruits were classified into the second group and the non-marketable yield including the diseased fruits belonged to the third group. The samples of red marketable fruits were chemically analyzed.

\subsection{Chemical Analysis}

Five mature red fruits were selected from each plot to determine the total soluble solid (TSS) and vitamin $C$ content. The chemical analysis of tomato fruits was performed in all years. The content of total soluble solid was determined by a Krüss DR201-95 handheld refractometer (A. Krüss Optronic $\mathrm{GmbH}$, Hamburg, Germany) and it was given by ${ }^{\circ}$ Brix. The determination of vitamin $\mathrm{C}$ content of the tomato yield was carried out using high performance liquid chromatography (HPLC) (Hitachi High-Technologies Europe $\mathrm{GmbH}$, Budapest, Hungary). Five grams of tomato fruit sample was weighed and milled, then $40 \mathrm{~mL}$ meta-phosphoric acid $\left(\mathrm{HPO}_{3}\right)$ was used to extract the vitamin $\mathrm{C}$ of fruits which was then measured by HPLC as described by Daood et al. [37].

\subsection{Statistical Analysis}

Data were evaluated by two-way analysis of variance (ANOVA) (year $\times$ irrigation and growth stage $\times$ irrigation) using SPSS 20.0 (IBM Hungary Ltd, Budapest, Hungary) for Windows software. The average values of treatments were compared by Duncan's multiple range test at $p<0.05$. Regression analysis was made to reveal the relationship between the traits related to photosynthesis (i.e., SPAD, $\mathrm{Fv} / \mathrm{Fm}$ ) and water circulation (i.e., stomatal conductance, canopy temperature) under different water supplies in two crop years. The relationship between the physiological traits and yield and quality measured in the same year was also evaluated using regression analysis.

\section{Results}

\subsection{Climate During the Growth}

During its development, processing tomato requires 400 to $800 \mathrm{~mm}$ of rainfall [38]. On the basis of total available water shown in Table 1, the weather was dry in years 2011 and 2015 and it was mildly wet in 2016 (Table 1) compared to the Hungarian average [39]. The distribution of natural precipitation varied from year to year during the different growth stages of tomato. In dry years (2011 and 2015) during flowering with fruit setting (ST2) and early fruit development (ST3) stages the amount of precipitation was similar, $44-42 \mathrm{~mm}$ and $24.7-29.1 \mathrm{~mm}$, respectively, however, in the mildly wet year (2016) during early fruit development and fruit ripening (ST3 and ST4) a lot of rain was detected (118.1 and $100.1 \mathrm{~mm}$ ) (Figure 1). In a dry (2015) and a mildly wet (2016) year, during the early fruit development (ST3) the air temperature was above $30^{\circ} \mathrm{C}$ through many days but it remained below $30^{\circ} \mathrm{C}$ in the dry year (2011) (Figure 1). The unequal distribution of precipitation and high daily temperature, particularly during the fruit development and ripening stages, significantly affected the yield and quality [40].

\subsection{Effect of Water Supply on the Traits and Yield}

During the generative stages of processing tomato the stomatal conductance changed depending the crop years, however, it was lower in 2015 than in 2011 under non-irrigated conditions (Table 2). 
During these periods, significant differences in the canopy temperature between the crop years was not detected. The chlorophyll fluorescence $(\mathrm{Fv} / \mathrm{Fm})$ and SPAD value of leaves were significantly lower under non-irrigated conditions (I0) than under irrigation in the dry year 2015, but no significant difference was detected in the mildly wet year (2016). In the wet year (2016), the plants produced a larger weight of fruits, and more unripe green and diseased fruits than in the dry years (2011, 2015) (Table 2). The fruit weight, total yield, and marketable yield were significantly lower but ${ }^{\circ}$ Brix of tomato fruits was higher under non-irrigated conditions (I0). Moderate water deficiency (DI), independent of the crop years, did not decrease the yields of tomato, however, the Brix yield and vitamin C content of fruits was the highest using deficit irrigation (DI). Under non-irrigated conditions (I0), the canopy temperature was significantly higher and chlorophyll fluorescence (Fv/Fm) was lower than that of deficit and well-irrigated plants (DI, WI). Nevertheless, during the different generative stages, the effect of water supply on the physiological processes of plants differed independently from the years (Figures 2 and 3 ).

Table 2. Effect of water supply on physiological traits, yield, and quality of processing tomato.

\begin{tabular}{|c|c|c|c|c|c|}
\hline & Water ${ }^{2}$ & 2011 & 2015 & 2016 & Average \\
\hline \multirow[t]{3}{*}{ Stomatal conductance $\left(\mu \mathrm{mol} \mathrm{m}{ }^{-2} \mathrm{~s}^{-1}\right) \mathrm{y}$} & I0 & $375.45 \mathrm{~b}$ & $414.45 \mathrm{~b}$ & - & $394.95 \mathrm{a}$ \\
\hline & DI & $640.20 a^{*}$ & $308.14 b$ & - & $474.17 \mathrm{a}$ \\
\hline & WI & $663.28 a^{*}$ & $251.25 \mathrm{~b}$ & - & $457.26 \mathrm{a}$ \\
\hline \multirow[t]{3}{*}{ Canopy temperature ${ }^{\circ} \mathrm{C}^{\mathrm{y}}$} & I0 & $27.83 \mathrm{a}$ & $29.51 \mathrm{a}$ & - & $28.67 \mathrm{a}$ \\
\hline & DI & $26.16 b^{*}$ & $24.61 b^{*}$ & - & $25.38 b^{*}$ \\
\hline & WI & $25.60 \mathrm{~b} *$ & $25.59 \mathrm{~b}$ * & - & $25.60 b^{*}$ \\
\hline \multirow[t]{3}{*}{$\mathrm{Fv} / \mathrm{Fm} \mathrm{y}$} & I0 & - & $0.662 \mathrm{~b}$ & $0.729 \mathrm{a}$ & $0.696 \mathrm{~b}$ \\
\hline & DI & - & $0.753 a *$ & $0.733 a$ & $0.743 a$ * \\
\hline & WI & - & $0.758 a^{*}$ & $0.738 a$ & $0.748 a^{*}$ \\
\hline \multirow[t]{3}{*}{ SPAD y } & I0 & - & $48.56 \mathrm{~b}$ & $56.70 \mathrm{a}$ & $52.63 \mathrm{a}$ \\
\hline & DI & - & $50.10 \mathrm{~b} *$ & $54.66 \mathrm{a}$ & $52.38 \mathrm{a}$ \\
\hline & WI & - & $52.36 a^{*}$ & $49.59 \mathrm{~b} *$ & 50.97 a \\
\hline \multirow[t]{3}{*}{ Fruit weight $(\mathrm{g})^{\text {y }}$} & I0 & $28.15 \mathrm{~b}$ & $15.44 \mathrm{c}$ & $68.47 \mathrm{a}$ & $37.35 \mathrm{~b}$ \\
\hline & DI & $48.13 b^{*}$ & $29.89 c^{*}$ & $67.65 \mathrm{a}$ & $48.56 a^{*}$ \\
\hline & WI & $41.00 b^{*}$ & $38.25 b^{*}$ & $61.69 \mathrm{a}$ & $46.98 \mathrm{a}^{*}$ \\
\hline \multirow[t]{3}{*}{ Total yield $\left(\mathrm{t} \mathrm{ha}^{-1}\right)^{\mathrm{y}}$} & I0 & $64.98 \mathrm{~b}$ & $19.83 \mathrm{c}$ & $111.08 \mathrm{a}$ & $65.30 \mathrm{~b}$ \\
\hline & DI & $133.59 \mathrm{a} *$ & $68.12 c^{*}$ & $120.75 \mathrm{~b}$ & $107.49 \mathrm{a}^{*}$ \\
\hline & WI & $98.89 \mathrm{~b} *$ & $85.97 b$ * & $125.39 \mathrm{a}^{*}$ & $103.15 \mathrm{a}^{*}$ \\
\hline \multirow[t]{3}{*}{ Marketing yield $\left(\mathrm{t} \mathrm{ha}^{-1}\right)^{\mathrm{y}}$} & I0 & $62.10 \mathrm{a}$ & $14.69 \mathrm{~b}$ & $61.22 \mathrm{a}$ & $46.00 \mathrm{~b}$ \\
\hline & DI & $131.12 \mathrm{a}^{*}$ & $56.45 c^{*}$ & $67.61 \mathrm{~b}$ & $85.06 \mathrm{a}$ * \\
\hline & WI & $96.23 \mathrm{a}^{*}$ & $68.41 c^{*}$ & $79.39 b^{*}$ & $81.34 \mathrm{a}^{*}$ \\
\hline \multirow[t]{3}{*}{ Verdant yield $\left(\mathrm{t} \mathrm{ha}^{-1}\right)^{\mathrm{y}}$} & I0 & $2.89 \mathrm{c}$ & $4.06 \mathrm{~b}$ & $9.41 \mathrm{a}$ & $5.45 \mathrm{a}$ \\
\hline & DI & $2.47 \mathrm{c}$ & $3.73 \mathrm{~b}$ & $12.97 a^{*}$ & $6.39 \mathrm{a}$ \\
\hline & WI & $1.89 \mathrm{~b}$ * & $1.85 b^{*}$ & $6.83 a^{*}$ & $3.52 \mathrm{a}$ \\
\hline \multirow[t]{3}{*}{ Diseased yield $\left(\mathrm{t} \mathrm{ha} \mathrm{a}^{-1}\right)^{\mathrm{y}}$} & I0 & $2.87 \mathrm{~b}$ & $1.08 \mathrm{c}$ & $40.46 \mathrm{a}$ & $14.80 \mathrm{a}$ \\
\hline & DI & $2.48 c^{*}$ & $7.94 b$ * & 40.17 a & $16.86 \mathrm{a}$ \\
\hline & WI & $1.88 c^{*}$ & $12.98 b$ * & $39.17 \mathrm{a}$ & $18.01 \mathrm{a}$ \\
\hline \multirow[t]{3}{*}{${ }^{\circ}$ Brix $y$} & I0 & $6.68 \mathrm{~b}$ & $8.03 \mathrm{a}$ & $3.65 c$ & $6.12 \mathrm{a}$ \\
\hline & DI & $5.80 a^{*}$ & $5.03 \mathrm{~b}$ * & $4.45 c^{*}$ & $5.09 b^{*}$ \\
\hline & WI & $5.45 a^{*}$ & $3.73 b^{*}$ & $3.55 \mathrm{~b}$ & $4.24 c^{*}$ \\
\hline \multirow[t]{3}{*}{ Brix yield $\left(\mathrm{t} \mathrm{ha}{ }^{-1}\right)^{y}$} & I0 & $4.10 \mathrm{a}$ & $1.18 \mathrm{c}$ & $2.24 \mathrm{~b}$ & $2.50 \mathrm{c}$ \\
\hline & DI & $7.60 a^{*}$ & $2.83 \mathrm{~b}$ * & $3.02 b$ * & $4.48 \mathrm{a}^{*}$ \\
\hline & WI & $5.14 \mathrm{a}^{*}$ & $2.55 \mathrm{~b} *$ & $2.88 \mathrm{~b}^{*}$ & $3.52 b^{*}$ \\
\hline \multirow[t]{3}{*}{$\operatorname{Vitamin} C\left(\mu g g^{-1}\right)^{y}$} & I0 & $405.75 \mathrm{a}$ & $329.95 \mathrm{~b}$ & $330.53 \mathrm{~b}$ & $355.41 \mathrm{~b}$ \\
\hline & DI & $501.25 a^{*}$ & $286.00 c^{*}$ & $418.24 b^{*}$ & $401.83 \mathrm{a}^{*}$ \\
\hline & WI & $375.00 \mathrm{a}$ & $272.88 c^{*}$ & $333.55 \mathrm{~b}$ & $327.14 \mathrm{~b}$ \\
\hline
\end{tabular}

${ }^{1}$ Marketing yield $=$ red colored fruits,${ }^{2} \mathrm{I} 0=$ non-irrigation, $\mathrm{DI}=$ deficit irrigation, $\mathrm{WI}=$ regular irrigation. ${ }^{\mathrm{y}}$ Means within a row following different letters are significantly different at $p<0.05$ using Duncan's multiple range test.

* Significantly different from the I0 at $p<0.05$. 
At the beginning of flowering, the stomatal conductance was very low independent of the water supply condition, and canopy temperature was moderate high $\left(25\right.$ and $\left.26^{\circ} \mathrm{C}\right)$ (Figure 2). Higher canopy temperature was measured during early fruit development (ST3) than at earlier stages. During this period, under non-irrigated conditions (I0) the canopy temperature measured was the highest, exceeding $30^{\circ} \mathrm{C}$ (Figure 2A). The irrigation (DI, WI) resulted in a significant decrease in the canopy temperature during both the ST2 and ST3 stages of development of tomato (Figure 2A). The highest stomatal conductance was measured during flowering with fruit setting (ST2) then it decreased during early fruit development (ST3), however, the largest effect of water supply on the stomatal conductance was detected during these periods (Figure 2B).
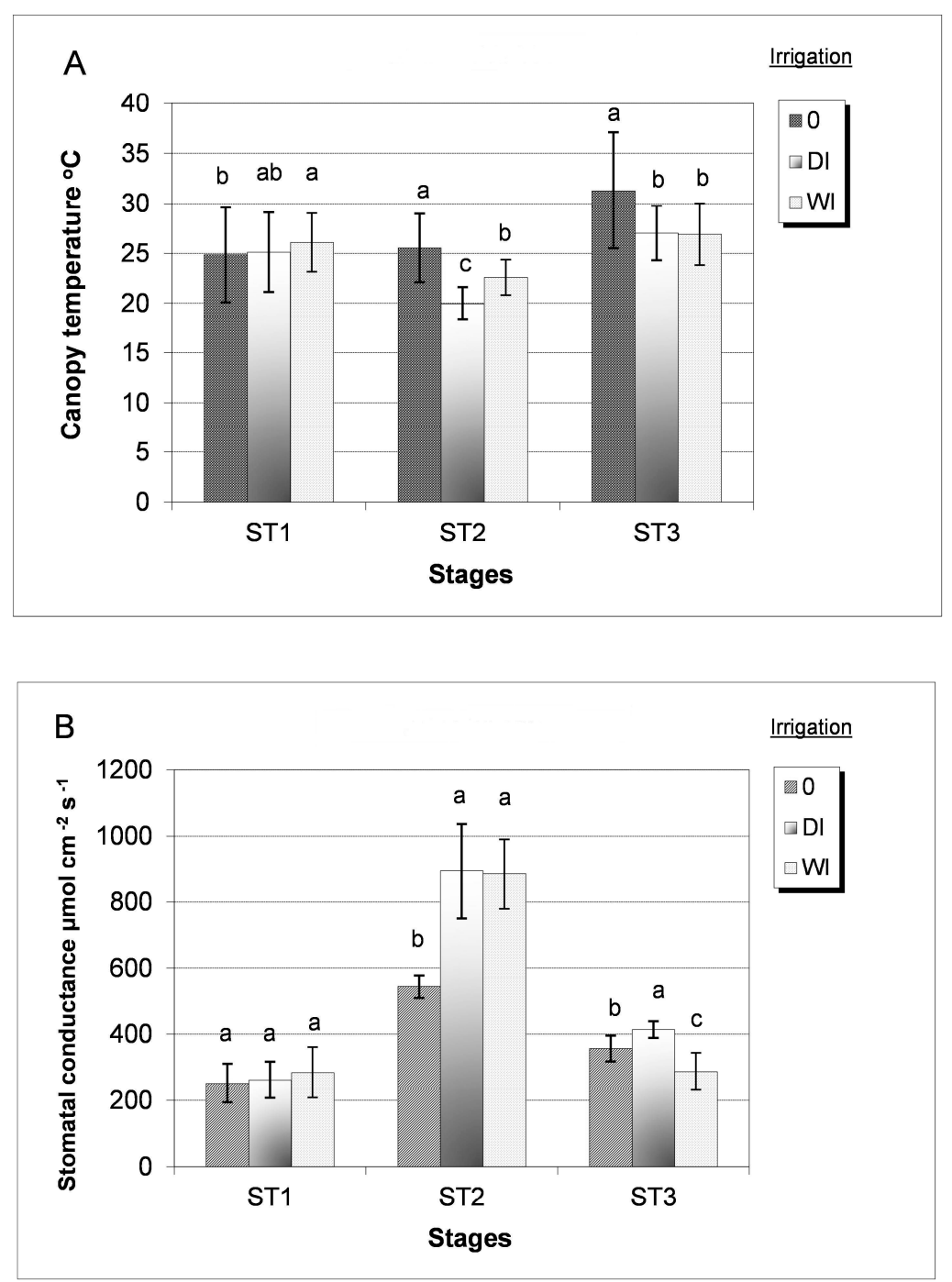

Figure 2. Effect of water supply conditions on canopy temperature (A) and stomatal conductance (B) during the growth stages (ST1 at beginning of flowering, ST2 during flowering with fruit development, ST3 during early fruit development) under non-irrigation (I0), deficit irrigation (DI), and regular irrigation (WI). Data presents the average of years 2011 and $2015 \pm$ SD. Means followed by different letters are significantly different at $p<0.05$ using Duncan's multiple range test.

Chlorophyll fluorescence during ST2 was as high as in ST1 for both the irrigated treatments (Figure 3A). Nevertheless, high chlorophyll content (53 and 54 SPAD values) in the leaves was measured during the ST1 and ST2 periods of tomato in all treatments (Figure 3B). Water scarcity (I0) resulted in the largest decrease in the Fv/Fm during flowering with fruit setting (ST2) and early fruit development (ST3). Irrigation (DI, WI) resulted in chlorophyll fluorescence (Fv/Fm) remaining high 
during the ST2 period and it decreased to a lesser extent during the early fruit development (ST3) period (Figure 3A). The SPAD value was high in each stage of development of plants grown under non-irrigated conditions, however it decreased significantly only in the well-irrigated plants during early fruit development (ST3) (Figure 3B).
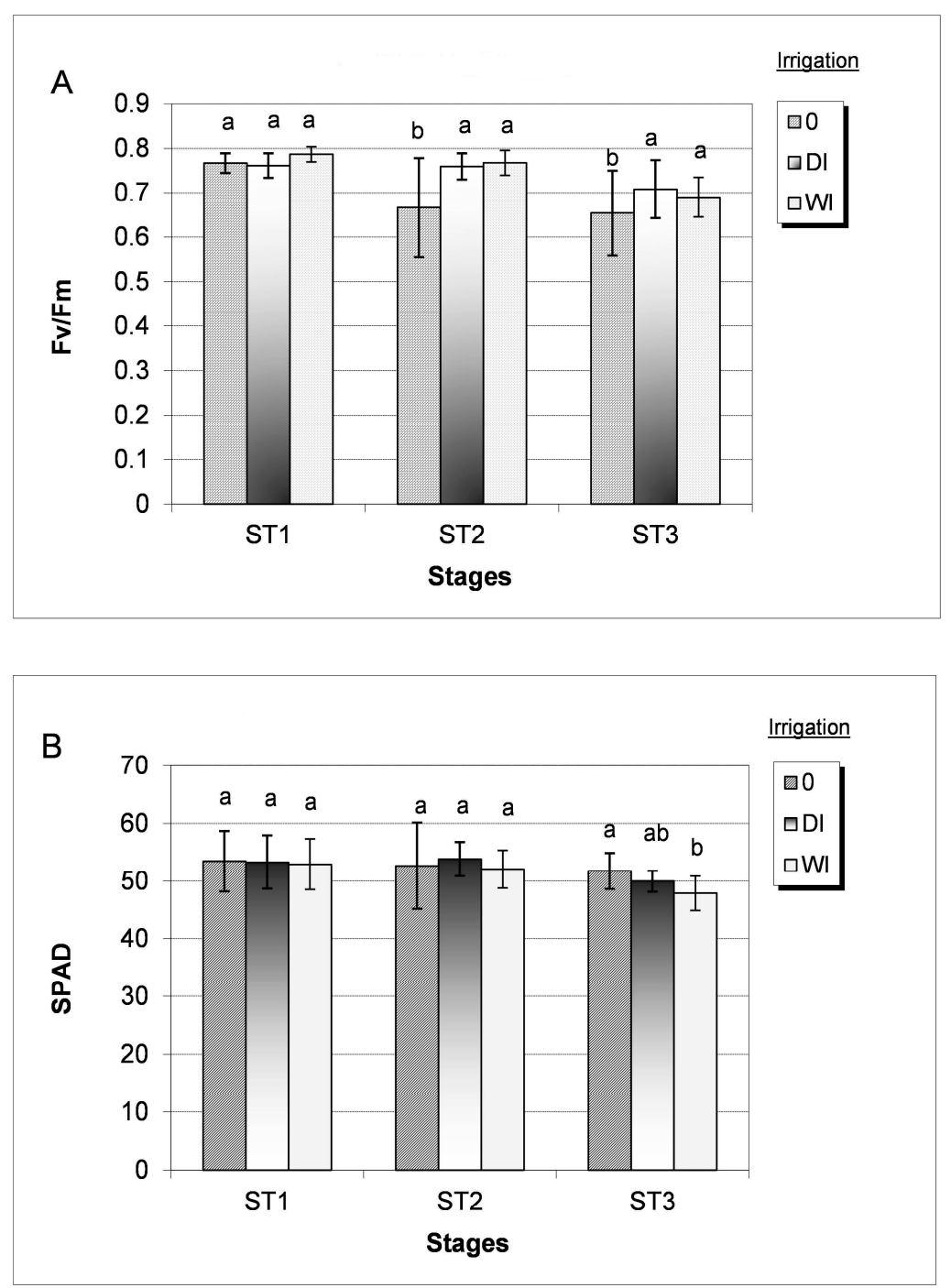

Figure 3. Effect of water supply conditions on chlorophyll fluorescence (Fv/Fm) (A) and SPAD (B) during the growth stages (ST1 at beginning of flowering, ST2 during flowering with fruit development, ST3 during early fruit development) under non-irrigation $\left(\mathrm{I}_{0}\right)$, deficit irrigation (DI), and regular irrigation (WI). Data presents the average of years 2015 and $2016 \pm$ SD. Means followed by different letters are significantly different at $p<0.05$ using Duncan's multiple range test.

\subsection{Relationships between Physiological Traits and Yield and Fruit Quality}

The relationships between the physiological traits measured during generative periods were examined under different water supply conditions independent from the crop years, however their relationships with the yield and quality were evaluated in the same year. The sensitive phases of development in processing tomato range from flowering to early fruit development when drought determines the yield. The water deficiency caused a larger change in the physiological traits during flowering with fruit setting than during early fruit development (Figures 2 and 3), therefore, the relationships of the water circulation-related traits and photosynthesis-related traits between the yield and fruit quality of tomato have been tested during this period (Tables 3-5). In dry years (2011 
and 2015), under non-irrigated conditions (I0), during flowering with fruit setting (ST2), the canopy temperature correlated negatively with the yield and vitamin $C$ content of fruits of tomato but its correlation with the soluble solid content $\left({ }^{\circ}\right.$ Brix) was positive (Table 3). Nevertheless, a positive significant correlation between the stomatal conductance and yield and vitamin $C$ content of fruit was detected but it was negative with the ${ }^{\circ}$ Brix. Under this growing condition, the SPAD value measured during the flowering with fruit setting period correlated with the canopy temperature $(r=0.8746)$ and the weight of fruits and the expected yield but its correlation was negative with the soluble solid content of fruits ( ${ }^{\circ}$ Brix) (Table 3). At the same time, a weak relationship between Fv/Fm and canopy temperature and yield was recorded. Under severe drought (I0), an increase in the canopy temperature was associated with a decreasing stomatal conductance $(\mathrm{r}=-0.7911)$ and an increasing soluble solid content of fruits ( ${ }^{\circ}$ Brix $)(r=0.9224)$, but the high canopy temperature contributed indirectly to the decrease in the yield of tomato.

Under water deficiency (DI), using deficit irrigation, a positive correlation between the SPAD value and canopy temperature $(\mathrm{r}=0.9416)$ and weight of fruits and yield was found. Under this condition, the relative chlorophyll content, i.e., SPAD value, related to the accumulation of vitamin $C$ of tomato fruits $(\mathrm{r}=0.9337)$ (Table 4$)$. Under dry conditions (I0 and DI), canopy temperature measured during flowering with fruit setting had a negative relationship with the fruit weight and yield but the trend of this correlation with the ${ }^{\circ}$ Brix and vitamin $C$ of tomato fruit was dependant on the degree of water stress (Tables 3 and 4 ).

Under regular irrigation (WI), a negative relationship between the SPAD and canopy temperature was found but this was positive with the stomatal conductance during flowering with fruit setting, independent of the crop years (Table 5). During this period, under well-irrigated conditions, the stomatal conductance had a more important role in the marketable yield and nutritional quality of tomato than that of SPAD on the basis of the correlation shown in Table 5. Stomatal conductance showed a closer relationship with the soluble solid content of fruits ( ${ }^{\circ}$ Brix) of the well-irrigated tomato plants $(r=0.9466)$ than with those grown under dry conditions (I0).

It can be established that under regularly irrigated condition, the SPAD, Fv/Fm, and canopy temperature related to the stomatal conductance, however, only stomatal conductance and canopy temperature significantly influenced the yield and quality of the tomato. Under water scarcity (I0, DI) during flowering with fruit setting, SPAD correlated positively with the canopy temperature and the fruit weight and yield but negatively with the soluble solid content ( ${ }^{\circ}$ Brix) of tomato. Under well-irrigated conditions during flowering with fruit setting, the low canopy temperature was associated with low SPAD values which resulted in an increase in light absorption and intensive photosynthesis that was proven by the significant correlation between the SPAD value and stomatal conductance. Nevertheless, the stomatal conductance had significant influence on the fruit weight and quality of tomato but SPAD did not. Stomatal conductance as a water circulation-related trait had a positive effect on the yield under both non-irrigated conditions (I0) and well-irrigated conditions WI). Under these conditions (I0, WI), the canopy temperature and stomatal conductance showed a close relationship with the ${ }^{\circ}$ Brix and vitamin $C$ content of tomato fruits. Under water scarcity, during the generative stages of development of tomato, the measurement of SPAD can also be used to predict the expected yield, while chlorophyll fluorescence $(\mathrm{Fv} / \mathrm{Fm})$ cannot predict it based on the correlations shown in Table 4. 
Table 3. Correlation coefficients $(\mathrm{r})$ and significance levels between physiological traits and yield and quality of tomato under non-irrigated (I0) conditions, $\mathrm{n}=8$.

\begin{tabular}{|c|c|c|c|c|c|c|c|c|}
\hline Traits ${ }^{1}$ & Fv/Fm & $\mathrm{CT}\left({ }^{\circ} \mathrm{C}\right)$ & $\frac{g_{s}}{\left(\mu \mathrm{mol} \mathrm{m} \mathrm{m}^{-2} \mathrm{~s}^{-1}\right)}$ & Fruit Weight (g) & $\begin{array}{l}\text { Marketing Yield } \\
\quad\left(\mathrm{t} \mathrm{ha}^{-1}\right)\end{array}$ & $\begin{array}{l}\text { Total Yield } \\
\left(\text { t ha }^{-1}\right)\end{array}$ & ${ }^{\circ}$ Brix & $\begin{array}{c}\text { Vitamin C } \\
\left(\mu g^{-1}\right)\end{array}$ \\
\hline SPAD & 0.2539 & $0.8746^{* *}$ & $-0.6651 *$ & $0.8655^{* *}$ & $0.8405^{* *}$ & $0.8443^{* *}$ & $-0.8698^{* *}$ & 0.0797 \\
\hline $\mathrm{Fv} / \mathrm{Fm}$ & - & 0.4069 & 0.2088 & 0.4505 & 0.3669 & 0.4000 & -0.4558 & $-0.5714+$ \\
\hline $\mathrm{CT}\left({ }^{\circ} \mathrm{C}\right)$ & & - & -0.7911 * & $-0.9843^{* * *}$ & $-0.9544^{* * *}$ & $-0.9539 * * *$ & $0.9224^{* * *}$ & -0.6661 * \\
\hline $\mathrm{g}_{\mathrm{s}}\left(\mu \mathrm{mol} \mathrm{m} \mathrm{m}^{-2} \mathrm{~s}^{-1}\right)$ & & & - & $0.6851 *$ & 0.7153 * & 0.7383 * & $-0.7161 *$ & $0.6258 *$ \\
\hline
\end{tabular}

Table 4. Correlation coefficients ( $\mathrm{r}$ ) and significance levels between physiological traits and yield and quality of tomato under deficit irrigation $(\mathrm{DI}), \mathrm{n}=8$.

\begin{tabular}{|c|c|c|c|c|c|c|c|c|}
\hline Traits ${ }^{1}$ & Fv/Fm & $\mathrm{CT}\left({ }^{\circ} \mathrm{C}\right)$ & $\left(\mu \mathrm{mol} \mathrm{m}^{-2} \mathrm{~s}^{-1}\right)$ & $\begin{array}{l}\text { Fruit Weight } \\
\text { (g) }\end{array}$ & $\begin{array}{l}\text { Marketing Yield } \\
\quad\left(\mathrm{t} \mathrm{ha}^{-1}\right)\end{array}$ & $\begin{array}{l}\text { Total Yield } \\
\left(\mathrm{t} \mathrm{ha} \mathbf{a}^{-1}\right)\end{array}$ & ${ }^{\circ}$ Brix & $\begin{array}{l}\text { Vitamin } C \\
\left(\mu g g^{-1}\right)\end{array}$ \\
\hline SPAD & 0.1608 & $0.9416^{* * *}$ & -0.2624 & $0.9256^{* * *}$ & $0.8482 * *$ & $0.9465^{* * *}$ & $-0.6279 *$ & $0.9337 * * *$ \\
\hline $\mathrm{Fv} / \mathrm{Fm}$ & - & 0.0266 & 0.2012 & -0.1103 & -0.0961 & -0.0799 & 0.3988 & 0.2915 \\
\hline $\mathrm{CT}\left({ }^{\circ} \mathrm{C}\right)$ & & - & -0.3645 & $-0.9426^{* * *}$ & $-0.9403^{* * *}$ & $-0.9573^{* * *}$ & -0.7197 * & $-0.9852 * * *$ \\
\hline $\mathrm{g}_{\mathrm{s}}\left(\mu \mathrm{mol} \mathrm{m} \mathrm{m}^{-2} \mathrm{~s}^{-1}\right)$ & & & - & 0.3026 & 0.2657 & 0.3018 & 0.1411 & 0.4287 \\
\hline
\end{tabular}

${ }^{1} \mathrm{~g}_{\mathrm{s}}=$ stomatal conductance, $\mathrm{CT}=$ canopy temperature; ${ }^{*} p<0.05,{ }^{* *} p<0.01,{ }^{* * *} p<0.001$.

Table 5. Correlation coefficients $(\mathrm{r})$ and significance levels between physiological traits and yield and quality of tomato under regular irrigation $(\mathrm{WI}), \mathrm{n}=8$.

\begin{tabular}{|c|c|c|c|c|c|c|c|c|}
\hline Traits ${ }^{1}$ & Fv/Fm & $\mathrm{CT}\left({ }^{\circ} \mathrm{C}\right)$ & $\underset{\left(\mu \mathrm{mol} \mathrm{m} \mathrm{m}^{-2} \mathrm{~s}^{-1}\right.}{\mathrm{g}_{\mathrm{s}}}$ & $\begin{array}{c}\text { Fruit Weight } \\
\text { (g) }\end{array}$ & $\begin{array}{l}\text { Marketing Yield } \\
\left(\mathrm{t} \mathrm{ha} \mathbf{a}^{-1}\right)\end{array}$ & $\begin{array}{l}\text { Total Yield } \\
\left(\mathrm{t} \mathrm{ha}^{-1}\right)\end{array}$ & ${ }^{\circ}$ Brix & $\begin{array}{l}\text { Vitamin C } \\
\left(\mu g^{-1}\right)\end{array}$ \\
\hline SPAD & -0.3398 & -0.5553 * & $0.7965 * *$ & -0.5242 & -0.3728 & -0.5331 & -0.1572 & -0.2215 \\
\hline $\mathrm{Fv} / \mathrm{Fm}$ & - & 0.4867 & $-0.5918 *$ & 0.4068 & -0.1392 & 0.4958 & 0.0500 & 0.4035 \\
\hline $\mathrm{CT}\left({ }^{\circ} \mathrm{C}\right)$ & & - & $-0.9716^{* * *}$ & $-0.7743^{* *}$ & $-0.8267 * *$ & $-0.6744^{*}$ & $-0.9904^{* * *}$ & $-0.9471^{* * *}$ \\
\hline $\mathrm{g}_{\mathrm{s}}\left(\mu \mathrm{mol} \mathrm{m} \mathrm{m}^{-2} \mathrm{~s}^{-1}\right)$ & & & - & $0.7506^{* *}$ & $0.6975+$ & $0.5962+$ & $0.9431^{* * *}$ & $0.9466^{* * *}$ \\
\hline
\end{tabular}

${ }^{1} \mathrm{~g}_{\mathrm{s}}=$ stomatal conductance, $\mathrm{CT}=$ canopy temperature; ${ }^{*} p<0.05,{ }^{* *} p<0.01,{ }^{* * *} p<0.001,+p<0.1$. 


\section{Discussion}

In field conditions, the physiological variables of plants as manifested phenotype characters can be monitored by the use of non-invasive methods such as stomatal conductance gas exchange, chlorophyll fluorescence, and chlorophyll content of leaves under different environmental stresses [41]. The tomato plants grown under non-irrigated conditions are unable to obtain water from the soil to meet the demands of evapotranspiration, therefore the canopy temperature rises and the high canopy temperature can be related to decreased stomatal conductance [4]. The results of stomatal conductance measured under different water supply conditions have been contradictory. Tan [4] observed that there was no significant difference in canopy temperature and stomatal conductance between the different irrigation levels, while others [42] found that under water scarcity the decrease in the stomatal conductance, depending on the varieties, was different in comparison with the well-watered conditions. Nevertheless, the water demands of plants during the developmental stages differ which determines their responses to water deficiency. The results showed that during the flowering with fruit setting period (ST2) the canopy temperature was higher $\left(25.5^{\circ} \mathrm{C}\right)$ and stomatal conductance was lower (543.3 $\mu \mathrm{mol} \mathrm{m} \mathrm{m}^{-2} \mathrm{~s}^{-1}$ ) in the tomato plants grown under non-irrigated conditions compared with that of well-irrigated ones. Under this growing condition (I0) during early fruit development (ST3), a $22 \%$ increase in the canopy temperature resulted in a $34 \%$ decrease in the stomatal conductance in comparison with the ST2 period. Under different irrigation conditions (DI and WI), during fruit setting (ST2) a low canopy temperature $\left(19.9^{\circ} \mathrm{C}\right.$ and $\left.22.6^{\circ} \mathrm{C}\right)$ and high stomatal conductance (893.4 and $884.8 \mu \mathrm{mol} \mathrm{m}^{-2} \mathrm{~s}^{-1}$ ) indicated the undisturbed photosynthesis and water circulation of plants. Following this period, during early fruit development (ST3), stomatal conductance was higher by $40 \%$ for the deficit irrigated plants than that of well-irrigated ones while the canopy temperature was the same $\left(27^{\circ} \mathrm{C}\right)$. This phenomenon is probably due to the activation of osmotic adjustment under water deficiency.

A large part of the visible light absorbed by photosynthetic pigments such as chlorophyll is used for the photosynthetic quantum conversion [43]. Under severe dry conditions, a high canopy temperature can result in the degradation of chlorophyll therefore the absorption of light decreases in the chloroplast and the reflectance increases, which manifests itself as large SPAD values. Therefore, the high SPAD and canopy temperatures trigger the decrease in stomatal conductance, resulting in a decrease in photosynthesis and the retardation of development of the plant which leads to low yield production. This was confirmed by the findings when the SPAD value measured during flowering with fruit setting was increased with the rising canopy temperature based on their correlations. The SPAD indirectly influenced the weight of tomato fruits and final yield under drought (I0). It can be explained by the fact that during early fruit development the high canopy temperature contributed to a moderate stomatal conductance (Figure 2) and reduced photosynthesis thus small weighed fruits and low yields are produced by the non-irrigated plants. A positive relationship between SPAD and marketable yield and vitamin $C$ content of tomato fruits was found but it was negative with the soluble solid content $\left({ }^{\circ}\right.$ Brix) under deficit irrigation. Contrary to our results others $[12,44]$ found that when the tomato crop was irrigated with a smaller volume of water, the plants transferred more sucrose into the sink organs therefore the soluble solid content and vitamin $C$ content of fruits was enhanced with the translocation of assimilates from the leaves into the fruits. A strong significant relationship was also found between the SPAD value of the leaf and the dry matter content of yield under water deficiency [45].

Under drought stress, the efficiency of photosynthetic systems (PSI-PSII) can be controlled by the measurements of chlorophyll fluorescence [14,28]. The maximum photochemical quantum yield of PSII, i.e., $\mathrm{Fv} / \mathrm{Fm}$ value, has been considered to be the most suitable for the evaluation of the photosynthetic process [30]. The ideal performance of the photosynthetic system exists at $0.823 \mathrm{Fv} / \mathrm{Fm}$ in unstressed blueberry plants [25], and the Fv/Fm can be 0.7 value in drought tolerant transgenic tomato plants [30]. This finding showed that tomato is very sensitive to water stress during the flowering with fruits setting and fruit development period under non-irrigated conditions. Under this growing condition, at high temperatures (Figure 1) the Fv/Fm decreased by 14\% during the fruit setting and early fruit 
development stages in comparison with that of the beginning of flowering. Nevertheless, during these periods, Fv / Fm remained relatively high (0.70-0.77) for the deficit irrigated and well-irrigated plants. High Fv/Fm values were detected in heat stress tolerant tomato genotypes and it was low in the sensitive ones [46] and blueberry varieties [47]. Others [18] considered that the SPAD would be a drought stress marker because an increasing SPAD value was associated with decreasing yield depending on the varieties. Under water deficiency (DI), during flowering with fruit setting (ST2), the SPAD value of the leaves was high (53.9), then a small (7\%) decrease was measured during early fruit development (ST3) compared to the previous stages (Figure 3B). This phenomenon proved that the effect of deficit irrigation on the traits related to photosynthesis (i.e., SPAD and Fv / Fm) and the yield was dependent on the weather of the crop years; it did not predominate in mildly wet years such as 2016. These results also confirmed that Uno Rosso F1 processing tomato has some drought tolerance that was proven by the results of yield shown in Table 2.

It can be established that under water scarcity (I0, DI) the SPAD value measured during flowering with fruit setting of tomato through photosynthesis indirectly relates to the weight of fruits and marketable yield, while chlorophyll fluorescence (Fv/Fm) does not. The change in stomatal conductance during the generative stages of development determines the yield production of the tomato plants under severe drought and regularly irrigated conditions.

\section{Conclusions}

In dry years, during early fruit development periods (ST3) of non-irrigated plants, when the canopy temperature exceeded $30{ }^{\circ} \mathrm{C}$ and the stomatal conductance was relatively low, the yield decreased. During the fruit setting and early fruit development stages of tomato the chlorophyll fluorescence $(\mathrm{Fv} / \mathrm{Fm})$ was significantly lower for non-irrigated plants than the irrigated ones. Under water scarcity (I0, DI) during flowering with fruit setting, the relative chlorophyll content of leaves (SPAD) correlated positively with the canopy temperature and yield but its correlation was negative with the soluble solid content $\left({ }^{\circ}\right.$ Brix). During this period, under well-irrigated conditions, the low canopy temperature associated with the low SPAD value and high stomatal conductance had a significant effect on the yield and quality of tomato. Deficit irrigation (DI) did not significantly decrease the yield of tomato compared to the well-irrigated plants which was due to the defensive mechanisms including stomatal conductance and canopy temperature as well as the SPAD value of leaves during the early fruit development stage. The relationship between these physiological traits and yield and quality of tomato can also be used for selection in breeding programs.

Author Contributions: E.N. analyzed the data and wrote the paper, A.N. and A.B. performed the experiments, Z.P. designed the experiments, A.N., Z.P., and L.H. corrected and improved the paper.

Funding: This research was funded by the Ministry of Human Capacities grant Higher Education Institutional Excellence Program in the framework of the water related research of Szent István University, and grant number EFOP-3.6.3-VEKOP-16-2017-00008 and 1783-3/2018/FEKUTSTRAT.

Conflicts of Interest: The authors declare no conflict of interest.

\section{References}

1. Helyes, L.; Varga, G. Irrigation demand of tomato according to the results of three decades. Acta Hortic. 1994, 376, 323-328. [CrossRef]

2. Sass-Kiss, A.; Kiss, J.; Milotay, P.; Kerek, M.M.; Tóth-Markus, M. Differences in anthocyanin and carotenoid content of fruits and vegetables. Food Res. Int. 2005, 38, 1023-1029. [CrossRef]

3. Patanè, C.; Tringali, S.; Sortino, O. Effects of deficit irrigation on biomass, yield, water productivity and fruit quality of processing tomato under semi-arid Mediterranean climate conditions. Sci. Hortic. 2011, 129, 590-596. [CrossRef]

4. Tan, C.S. Tomato yield-evapotranspiration relationships, seasonal canopy temperature and stomatal conductance as affected by irrigation. Can. J. Plant Sci. 1993, 73, 257-264. [CrossRef] 
5. $\quad$ Pires, R.C.M.; Furlani, P.R.; Ribeiro, R.V.; Junior, D.B.; Sakai, E.; Lourençăo, A.L.; Neto, A.T. Irrigation frequency and substrate volume effects in the growth and yield of tomato plants under greenhouse conditions. (Piracicaba, Braz.) Sci. Agric. 2011, 68, 400-405. [CrossRef]

6. Lahoz, I.; Pérez-de-Castro, A.; Valcárcel, M.; Macua, J.I.; Beltrán, J.; Roselló, S.; Cebolla-Cornejo, J. Effect of water deficit on the agronomical performance and quality of processing tomato. Sci. Hortic. 2016, 200, 55-65. [CrossRef]

7. Fereres, E.; Evans, R.G. Irrigation of fruit trees and vines: An introduction. Irrig. Sci. 2006, $24,55-57$. [CrossRef]

8. Zhang, H.; Huang, G.; Xu, X.; Xiong, Y.; Huang, Q. Estimating evapotranspiration of processing tomato under plastic mulch using the SIMDualKc model. Water 2018, 10, 1088. [CrossRef]

9. Sing, S.K.; Reddy, K.R. Regulation of photosynthesis, fluorescence, stomatal conductance and water-use efficiency of cowpea [Vigna unguiculata (L.) Walp.] under drought. J. Photoch. Photobiol. B 2011, 105, 40-50. [CrossRef] [PubMed]

10. Dorji, K.; Behboudian, M.; Zegbe-Dominguez, J. Water relations, growth, yield, and fruit quality of hot pepper under deficit irrigation and partial rootzone drying. Sci. Hortic. 2005, 104, 137-149. [CrossRef]

11. Kulkarni, M.; Phalke, S. Evaluating variability of root size system and its constitutive traits in hot pepper (Capsicum annum L.) under water stress. Sci. Hortic. 2009, 120, 159-166. [CrossRef]

12. Agbna, G.H.D.; Donglia, S.; Zhipeng, L.; Elshaikha, N.A.; Guangchenga, S.; Timm, L.C. Effects of deficit irrigation and biochar addition on the growth, yield, and quality of tomato. Sci. Hortic. 2017, 222, 90-101. [CrossRef]

13. Song, H.; Gao, J.F.; Gao, X.L.; Dai, H.P.P.; Zhang, P.; Feng, B.L.; Wang, P.K.; Chai, Y. Relations between photosynthetic parameters and seed yields of Adzuki bean cultivars (Vigna angularis). J. Integr. Agric. 2012, 9, 1453-1461. [CrossRef]

14. Ogweno, J.O.; Song, X.S.; Hu, W.H.; Shi, K.; Zhou, Y.H.; Yu, J.Q. Detached leaves of tomato differ in their photosynthetic physiological response to moderate high and low temperature stress. Sci. Hortic. 2009, 123, 17-22. [CrossRef]

15. Köksal, E.S. Hyperspectral reflectance data processing through cluster and principal component analysis for estimating irrigation and yield related indicators. Agric. Water Manag. 2011, 98, 1317-1328. [CrossRef]

16. Bőcs, A.; Pék, Z.; Helyes, L. Simultaneous impact of the different water supply and year type on processing tomato yield. Int. J. Hortic. Sci. Hung. 2011, 17, 79-81.

17. Cselőtei, L.; Helyes, L. The possibility of determining irrigation requirements by means of plant temperature. Acta Hortic. 1988, 220, 353-358. [CrossRef]

18. Nemeskéri, E.; Molnár, K.; Vígh, R.; Nagy, J.; Dobos, A. Relationships between stomatal behaviour, spectral traits and water use and productivity of green peas (Pisum sativum L.) in dry seasons. Acta Physiol. Plant. 2015, 37, 34. [CrossRef]

19. Nemeskéri, E.; Molnár, K.; Pék, Z.; Helyes, L. Effect of water supply on the water use-related physiological traits and yield of snap beans in dry seasons. Irrig. Sci. 2018, 36, 143-158. [CrossRef]

20. Pék, Z.; Szuvandzsiev, P.; Neményi, A.; Helyes, L. Effect of season and irrigation on yield parameters and soluble solids content of processing cherry tomato. Acta Hortic. 2015, 1081, 197-202. [CrossRef]

21. Prieto, M.H.; López, J.; Ballesteros, R. Influence of irrigation system and strategy of the agronomic and quality parameters of the processing tomatoes in Extremadura. Acta Hortic. 1999, 487, 575-579. [CrossRef]

22. Cahn, M.D.; Herrero, E.V.; Snyder, R.L.; Hanson, B.R. Water management strategies for improving fruit quality of drip irrigated processing tomatoes. Acta Hortic. 2001, 542, 111-117. [CrossRef]

23. Favati, F.; Lovelli, S.; Galgano, F.; Miccolis, V.; Di Tommaso, T.; Candido, V. Processing tomato quality as affected by irrigation scheduling. Sci. Hortic. 2009, 122, 562-571. [CrossRef]

24. Lambrev, P.H.; Miloslavina, Y.; Jahns, P.; Holzwarth, A.R. On the relationship between non-photochemical quenching and photoprotection of photosystem II. Biochim. Biophys. Acta Bioenerg. 2012, 1817, 760-769. [CrossRef] [PubMed]

25. Lobos, G.A.; Retamales, J.B.; Hancock, J.F.; Flore, J.A.; Cobo, N.; del Pozo, A. Spectral irradiance, gas exchange characteristics and leaf traits of Vaccinium corymbosum L'Elliott' grown under photo-selective nets. Environ. Exp. Bot. 2012, 75, 142-149. [CrossRef] 
26. Rosenqvist, E.; van Kooten, O. Chlorophyll fluorescence: A general description and nomenclature. In Practical Applications of Chlorophyll Fluorescence in Plant Biology; DeEll, J.R., Toivonen, P.M.A., Eds.; Kluwer Academic Publishers: Nor-well, MA, USA, 2003; pp. 32-77.

27. Estrada, F.; Escobar, A.; Romero-Bravo, S.; González-Talice, J.; Poblete-Echeverría, C.; Caligari, P.D.S.; Lobos, G.A. Fluorescence phenotyping in blueberry breeding for genotype selection under drought conditions, with or without heat stress. Sci. Hortic. 2015, 181, 147-161. [CrossRef]

28. Baker, N.R. Chlorophyll fluorescence: A probe of photosynthesis in vivo. Annu. Rev. Plant Biol. 2008, 59, 89-113. [CrossRef] [PubMed]

29. Peck, A.W.; McDonald, G.K. Adequate zinc nutrition alleviates the adverse effects of heat stress in bread wheat. Plant Soil 2010, 337, 355-374. [CrossRef]

30. Mishra, K.B.; Iannacone, R.; Petrozza, A.; Mishra, A.; Armentano, N.; La Vecchia, G.; Trtilek, M.; Cellini, F.; Nedbal, L. Engineered drought tolerance in tomato plants is reflected in chlorophyll fluorescence emission. Plant Sci. 2012, 182, 79-86. [CrossRef]

31. Knipling, E.B. Physical and physiological basis for the reflectance of visible and near-infrared radiation form vegetation. Rem. Sens. Environ. 1970, 1, 155-159. [CrossRef]

32. Carter, G.A.; Knap, A.K. Leaf optical properties in higher plants: Linking spectral characteristics to stress and chlorophyll concentrations. Am. J. Bot. 2001, 88, 677-684. [CrossRef] [PubMed]

33. Nemeskéri, E.; Sárdi, É.; Kovács-Nagy, E.; Stefanovits Bányai, É.; Nagy, J.; Nyéki, J.; Szabó, T. Studies on the drought responses of apple trees (Malus domestica Borkh.) grafted on different rootstocks. Int. J. Hortic. Sci. Hung. 2009, 15, 29-36.

34. Hsiao, T.C.; Heng, L.; Steduto, P.; Rojas-Lara, B.; Raes, D.; Fereres, E. Aquacrop- The FAO crop model to simulate yield response to water: III. Parameterization and testing for maize. Agron. J. 2009, 3, 448-459. [CrossRef]

35. Allen, R.G.; Pereira, L.S.; Raes, D.; Smith, M. Crop Evapotranspiration: Guidelines for Computing Crop Water Requirements; FAO Irrigation and Drainage Paper No 56; FAO: Rome, Italy, 1998.

36. Nagy, Z.; Daood, H.; Neményi, A.; Ambrózy, Z.; Pék, Z.; Helyes, L. Impact of shading net color on phytochemical contents in two chilli pepper hybrids cultivated under greenhouse conditions. Hort. Sci. Tech. 2017, 35, 418-430.

37. Daood, H.G.; Biacs, P.A.; Dakar, M.A.; Hajdu, F. Ion-pair chromatography and photodiode-array detection of vitamin C and organic acids. J. Chromatogr. Sci. 1994, 32, 481-487. [CrossRef]

38. Battilani, A.; Prieto, H.; Argerich, C.; Campillo, C.; Cantore, V. Tomato. In Crop Yield Response to Water; Steduto, P., Hsiao, T.C., Fereres, E., Raes, D., Eds.; FAO irrigation and drainage paper 66; Food and Agriculture Organization of the United Nations: Rome, Italy, 2012; pp. 192-198.

39. Spinoni, J.; Szalai, S.; Szentimrey, T.; Lakatos, M.; Bihari, Z.; Nagy, A.; Németh, Á.; Kovács, T.; Mihic, D.; Dacic, M.; et al. Climate of the Carpathian Region in the period 1961-2010: Climatologies and trends of 10 variables. Int. J. Climatol. 2015, 35, 1322-1341. [CrossRef]

40. Lovelli, S.; Potenza, G.; Castronuovo, D.; Perniola, M.; Candido, V. Yield, quality and water use efficiency of processing tomatoes produced under different irrigation regimes in Mediterranean environment. Ital. J. Agron. 2017, 12, 17-24. [CrossRef]

41. Baker, N.R.; Rosenqvist, E. Applications of chlorophyll fluorescence can improve crop production strategies: An examination of future possibilities. J. Exp. Bot. 2004, 55, 1607-1621. [CrossRef]

42. Giuliania, M.M.; Carucci, F.; Nardella, E.; Francavilla, M.; Ricciardi, L.; Lotti, C.; Gatta, G. Combined effects of deficit irrigation and strobilurin application on gas exchange, yield and water use efficiency in tomato (Solanum lycopersicum L.). Sci. Hortic. 2018, 233, 149-158. [CrossRef]

43. Cherif, J.; Derbel, N.; Nakkach, M.; von Bergmann, H.; Jemal, F.; Lakhdar, Z.B. Analysis of in vivo chlorophyll fluorescence spectra to monitor physiological state of tomato plants growing under zinc stress. J. Photoch. Photobiol. B: Biol. 2010, 101, 332-339. [CrossRef]

44. Qi, H.-Y.; Li, T.-L.; Zhang, J.; Wang, L.; Chen, Y.-H. Effects on sucrose metabolism, dry matter distribution and fruit quality of tomato under water deficit. Agri. Sci. China (English Edition) 2003, 2, 1253-1258.

45. Nemeskéri, E.; Molnár, K.; Helyes, L. Relationships of spectral traits with yield and nutritional quality of snap beans (Phaseolus vulgaris L.) in dry seasons. Arch. Agron. Soil Sci. 2018, 64, 1222-1239. [CrossRef] 
46. Zhou, R.; Yu, X.; Kjær, K.H.; Rosenqvist, E.; Ottosen, C.O.; Wu, Z. Screening and validation of tomato genotypes under heat stress using $\mathrm{Fv} / \mathrm{Fm}$ to reveal the physiological mechanism of heat tolerance. Environ. Exp. Bot. 2015, 118, 1-11. [CrossRef]

47. Chen, W.; Cen, W.; Chen, L.; Di, L.; Li, Y.; Guo, W. Differential sensitivity of four highbush blueberry (Vaccinium corymbosum L.) cultivars to heat stress. Pak. J. Bot. 2012, 44, 853-860. 